Cheng et al.

\title{
Expression of Estrogen Receptor Beta in Prostate Carcinoma Cells Inhibits Invasion and Proliferation and Triggers Apoptosis
}

\author{
Jennifer Cheng ${ }^{2}$, Eun Jig Lee ${ }^{2}$, Laird D. Madison ${ }^{2}$, and Gwendal Lazennec ${ }^{1 *}$. \\ ${ }^{1}$ INSERM U540, Molecular and Cellular Endocrinology of Cancers, \\ 60, rue de Navacelles, 34090 Montpellier, France. \\ ${ }^{2}$ Center for Endocrinology and Molecular Medicine, Northwestern University, \\ 303 East Chicago Avenue, Tarry Building 15-703, Chicago, Illinois, 60611 USA. \\ j-cheng2@,nwu.edu / Phone: 13125034134 / Fax: 13129089032 \\ ele423@northwestern.edu / Phone: 13125031612 / Fax: 13129089032 \\ 1dm@,northwestern.edu / Phone: 13125030486 / Fax: 13129089032 \\ lazennec@ montp.inserm.fr / Phone: 334670430 84 / Fax: 33467043084
}

\begin{abstract}
The involvement of estrogen receptor beta (ER $\beta$ ) in prostate carcinogenesis has been hypothesized. Several reports have shown that ER $\beta$ expression was decreased when prostate cells undergo neoplastic transformation, suggesting that it could play a tumor-suppressor role. By restoring ER $\beta$ expression in prostatic carcinoma cells by adenoviral delivery, we aimed to test this hypothesis. We observed that ER $\beta$ strongly inhibited the invasiveness and the growth of these cells. In addition, ER $\beta$ cells were undergoing apoptosis, as shown by quantification of Bax, PARP and caspase-3 expression. Our data suggest that ER $\beta$ acts as a tumor-suppressor by its anti-proliferative, anti-invasive and pro-apoptotic properties.
\end{abstract}

key words: estrogen receptor, apoptosis, proliferation, invasion, prostate cancer.

\section{* Corresponding author:}

Dr Gwendal Lazennec

INSERM U540 " Molecular and Cellular Endocrinology of Cancers ", 60, rue de Navacelles - 34090 Montpellier, France

Tel: (33) 4670430 84; Fax: (33) 467543084

E-mail: lazennec@montp.inserm.fr 
Cheng et al.

\section{Introduction}

Prostate cancer is one of the most common forms of cancer in males in developed countries [1]. The role of sex steroids in the biology of the prostate and prostate cancer remains unclear, despite nearly four decades of research since Charles Huggins dramatic demonstration of orchiectomy and endocrine therapy on prostate cancer [2]. Until 1996, it was thought that estrogen receptors (ER) are present only in a limited number of cells in the prostate, mainly in the stromal cells of the prostatic lobes and the posterior periurethral region, while the epithelial cells were reported to contain very low amounts of the receptors [3]. However, the recent discovery of a novel estrogen receptor (ER $\beta)$, cloned from rat prostate cDNA library, and abundantly expressed in rat and human prostate epithelium [4], suggests that prostate epithelium is also a direct target for estrogen action. Moreover, a recent study has shown that ER $\beta$ is the only estrogen receptor detected at the protein level in the morphologically normal developing human fetal prostate [5]. Since the identification of $\mathrm{ER} \beta$, many reports have shown that a loss of $\operatorname{ER} \beta$ expression is associated with progression of normal prostate epithelium into prostate cancers [6-9]. A similar down-regulation in ER $\beta$ expression is also noted in ovarian, breast or colon tumors [10-12]. These data and the observation that older ER $\beta$-null mice develop prostatic hyperplasia [13] have led to the hypothesis that the loss of ER $\beta$ may be a mechanism by which prostate epithelial cells escape normal control of proliferation [14]. The goal of this study was to determine whether restoration of ER $\beta$ expression in prostate cancer cells had major effect on proliferation, invasiveness and apoptosis of prostate cancer cells. 
Cheng et al.

\section{Materials and Methods}

\subsection{Recombinant adenovirus construction and propagation.}

The complete coding sequences of wild-type hER $\alpha$ and hER $\beta$ cDNAs were subcloned in BamHI site of the pACsk12CMV5 shuttle vector. To obtain recombinant viruses, permissive HEK-293 cells (human embryonic kidney cells) were cotransfected with the backbone or recombinant pACsk12CMV5-hER plasmid and with pJM17, which contains the remainder of the adenoviral genome as previously described $[15,16]$. In vivo recombination of the plasmids generates infectious viral particles Ad5 (backbone virus), Ad-hER $\alpha$ and Ad-hER $\beta$. Titered virus stocks were used to infect DU-145 prostate cancer cells.

\subsection{Cell Culture and infection}

DU-145 cells (ER-negative) were obtained from the American Type Culture Collection (ATCC Rockville, MD). Cells were maintained in MEM with 5\% FCS and penicillin/streptomycin (Invitrogen). DU-145 cells were weaned off steroids in phenol redfree MEM supplemented with 10\% CDFCS (charcoal dextran-treated FCS) 3 days before experiments. Cells were infected overnight at a multiplicity of infection (MOI) of 50. The next day, the medium was removed and replaced with fresh one.

\subsection{Transfections}

$3.10^{5}$ cells were plated in 6-well plates in phenol red-free MEM 10\% CDFCS $24 \mathrm{~h}$ before infection. Cells were then infected overnight as specified in 2.2. The next day, transfections were performed with lipofectamine according to the manufacturer's recommendations using $4 \mu \mathrm{g}$ of ERE2-TK-LUC luciferase reporter along with $0.8 \mu \mathrm{g}$ of the internal reference reporter plasmid (CMV-Gal) per well. After overnight lipofection, the medium was removed and the cells were placed into fresh medium supplemented with control vehicle ethanol or 
Cheng et al.

E2 $\left(10^{-8} \mathrm{M}\right) .24 \mathrm{~h}$ later, cells were harvested and assayed for luciferase activity on Centro LB960 Berthold luminometer. $\beta$-galactosidase was determined as previously described [15].

\subsection{Whole cell extract preparation and western blot.}

Cells were lyzed by sonication in $10 \mathrm{mM}$ Tris-HCl, $\mathrm{pH}$ 7.4, $1.5 \mathrm{mM}$ EDTA, and 10\% glycerol containing protease inhibitors. The resulting whole-cell extract proteins were subjected to SDS-PAGE followed by electrotransfer onto a nitrocellulose membrane. The following antibodies were used: Bax monoclonal antibody, B/9 (Santa Cruz Biotechnologies;1:500 dilution); and Poly (ADP-ribose) polymerase (PARP) monoclonal antibody, 4C10-5 (BD Pharmingen; $1 \mu \mathrm{g} / \mathrm{ml})$.

\subsection{Immunofluorescence}

$10^{6}$ cells were plated in a 6-well plate and infected with adenovirus at a multiplicity of infection (MOI) of 50. Paraformaldehyde fixed cells were incubated with primary antibody against cleaved caspase 3 (Cell Signaling Technologies) for 1 hour at room temperature in a humidified chamber. After washing with Tris-buffered saline (TBS) $+0.025 \%$ Tween, staining was performed using biotinylated secondary antibodies (ABC kit, Vector Laboratories), and streptavidin-FITC (1:100, Vector Laboratories). Cell images were analyzed using a Zeiss microscope (Axioskop, Carl Zeiss Inc., Oberkochen, Germany)

\subsection{Transwell Matrigel Invasion Assays}

Invasion were performed as previously described [15]. Briefly, DU-145 cells were plated 24 hours after infection (MOI 50) in the upper compartment filled with MEM 10\% CDFCS with $30 \mu \mathrm{g} / \mathrm{ml}$ fibronectin of a 24-well Transwell (Corning-Costar) on a polycarbonate filter ( $8 \mu \mathrm{m}$ pore size), which was pre-coated with $30 \mu \mathrm{g}$ of matrigel (Becton Dickinson). Cells migrating to the lower side of the filter and control cells in the 24-well plate were quantified using MTT uptake (Sigma Chemical Co., St. Louis, MO). 
Cheng et al.

\subsection{Cell proliferation Assays}

Cells were estrogen depleted for 3 days and then plated in 96 well plates at a density of 5000

cells/well and infected with adenovirus overnight (MOI 50). MEM 10\% CDFCS containing either ethanol or 10nM E2 was added to the cells after infection. Cell proliferation was measured with MTT. 
Cheng et al.

\section{Results}

\subsection{ER $\beta$ introduction in prostate cancer cells.}

To test this hypothesis of the involvement of ER $\beta$ in prostate cell growth, we decided to restore ER $\alpha$ and ER $\beta$ expression in the ER-negative prostate carcinoma cell line DU-145, by using ER $\alpha$ or ER $\beta$ encoding adenoviruses. Cells were mock infected (non-infected) or infected with backbone (Ad5), ER $\alpha$ (Ad-ER $\alpha$ ), or ER $\beta$ (Ad-ER $\beta$ ) adenoviruses. No detectable levels of $E R \alpha$ or $E R \beta$ proteins were seen by immunoblotting or immunofluorescence in uninfected or Ad5 infected cells, whereas adenoviral delivery enabled a high expression of ER $\alpha$ and ER $\beta$ proteins (data not shown). To further assess the functionality of the receptors, virally expressed ER $\alpha$ and $\operatorname{ER} \beta$ were able to transactivate an estrogen-responsive reporter construct when transfecting DU-145 cells (Fig. 1). Both receptors were active, even though $\mathrm{ER} \beta$ was a weaker activator than $\mathrm{ER} \alpha$, as previously shown in breast cancer cells $[15,17]$.

\subsection{ER $\beta$ inhibits prostate cancer cell invasiveness and growth}

We next examined the consequences of ER $\alpha$ or ER $\beta$ expression on the invasion potential of DU-145 cells by using matrigel-coated Transwell (Fig. 2A). Ad-ER $\alpha$ infected cells had the same invasion potential as Ad5 infected cells (Fig. 2A). With the addition of estradiol, a 30$40 \%$ decrease in invasion was observed. Interestingly, in ER $\beta$ infected cells, in the absence of estrogens, a 50\% decrease in invasion was observed. With the addition of E2, an even greater inhibition of invasion was observed, up to $70 \%$ of baseline (Fig. 2A).

In addition to invasion, another major goal of these experiments was to determine the effect of ER $\alpha$ and ER $\beta$ on proliferation in DU-145 cells. Ad-ER $\alpha$ infected cells in control medium had a proliferation profile similar to that of Ad5 infected cells (Fig. 2B). A 30\% decrease in 
Cheng et al.

proliferation was seen only in Ad-ER $\alpha$ cells treated with estradiol. On the contrary, Ad-ER $\beta$ cells displayed a $60 \%$ decreased proliferation in both control and estradiol treated conditions. These data suggest that although both ER $\alpha$ and $\mathrm{ER} \beta$ inhibit proliferation, $\mathrm{ER} \beta$ is a stronger regulator of cell growth than ER $\alpha$ in prostate cancer cells.

\subsection{ER $\beta$ is triggering apoptosis of prostate cancer cells}

We next hypothesized the potential involvement of apoptosis behind the decrease in proliferation seen in Ad-ER $\beta$ cells. To answer to this question, we analyzed the expression of several markers of apoptosis. Introduction of ER $\beta$ in DU-145 cells led to a strong increase in pro-apoptotic Bax levels (Fig. 3A). Poly (ADP-ribose) polymerase (PARP), a caspase target was also analyzed. Levels of cleaved PARP $(85 \mathrm{kDa})$ was increased in AdER $\beta$ infected cells compared to Ad5 infected cells. To further characterize the apoptosis seen in Ad-ER $\beta$ cells, immunofluorescence with anti-cleaved caspase 3 antibodies was performed (Fig. 3C). Introduction of ER $\beta$ in DU-145 cells led to peri-nuclear expression of cleaved caspase 3 (Fig. 3C). All these data suggest that cells expressing ER $\beta$ undergo apoptosis, which could contribute to the reduced proliferation observed.

\section{Discussion}

Prostate is considered together with ovary as one of the main tissue in terms of ER $\beta$ expression [4]. Moreover, several studies have shown a decreased expression of ER $\beta$ in prostate carcinoma compared to non pathological tissues [6-9]. The potential beneficial anti-neoplastic role of ER $\beta$ in prostate is thus crucial but remains to be demonstrated. To investigate the roles of $\mathrm{ER} \alpha$ and $\mathrm{ER} \beta$ in prostate, we used a prostate cancer cell line devoid of both endogenous receptors in which $\mathrm{ER} \alpha$ and $\mathrm{ER} \beta$ expression was restored using 
Cheng et al.

adenovirus delivery. Interestingly, a potent decrease in invasion (60\%) was observed with the introduction of ER $\beta$, which is in agreement with the situation found in breast cancer cells [15]. The results from the invasion assay also correlate with emerging clinical data. At least three different reports show that the loss or decrease in $\operatorname{ER} \beta$ expression is associated with higher Gleason grade tumors and prostate cancer with higher metastatic potential [6-8].

Concerning cell growth, the introduction of ER $\beta$ in DU-145 cells caused a strong inhibition of proliferation, in agreement with our previous data in breast cell carcinoma [15], and with the more recent studies showing that ER $\beta$ can also inhibit the proliferation of ER $\alpha$-positive breast cancer cells $[18,19]$. These data correlate well with the phenotype of ER $\beta$ knock-out animals ( $\beta$ ERKO) studies in which, most breast and prostate epithelial cells express the proliferation antigen Ki-67 [14]. Moreover, $80 \%$ of 1 year old $\beta E R K O$ animals show hyperplastic lesions in prostate, suggesting the loss of ER $\beta$ leads to an uncontrolled cellular proliferation. The mechanisms responsible for the reduced growth of cells expressing exogenously ER $\beta$ are beginning to be investigated. We and others have shown that ER $\beta$ was able to induce $\mathrm{p} 21^{\mathrm{Cip}-1}$ and $\mathrm{p} 27^{\mathrm{Kip}-1}$ expression, while decreasing cmyc, cyclin A, cyclin D1, cyclin E, Cdc25A, p45 (Skp2) levels [15,18,19]. Moreover, at least in ER $\alpha$-positive breast cancer cells, growth inhibition would result from an arrest in G2 phase of the cell cycle [18].

Concerning the fact that ER $\alpha$ decreases both the invasion and the proliferation in a ligand-dependent manner, several hypothesis can be raised. We have previously shown by a cDNA array screen and western blot analysis that introduction of ER $\alpha$ in ERnegative breast cancer cells leads to striking changes in gene expression. In particular, 
Cheng et al.

levels of $\mathrm{p} 21^{\mathrm{CIP}-1}, \mathrm{p} 27^{\mathrm{Kip}-1}$, macmarcks and TOB are increased, whereas $\mathrm{pRb}$ protein is hypo-phosphorylated, suggesting that these events could account for the estrogendependent observed growth inhibition [20]. In the same line, changes in integrin and BMP-4 [20] could also account for the observed inhibition of invasion observed after reintroduction of ER $\alpha$. For $E R \beta$, the situation is indeed different as this receptor inhibits both the invasion and the proliferation, mainly in a ligand-independent manner. We have previsously shown that ER $\beta$ could inhibit Interleukin-8 (IL-8) expression in a ligand independent manner [21]. Moreover IL-8 is able to increase invasion, which suggests that at least part of the effets of ER $\beta$ on invasion could involve a decreased expression of IL-8. The mechanisms accounting for the ligand-independent inhibition of growth remain elusive. We cannot entirely rule out the possibility of an endogenous cryptic ER $\beta$ ligand. Indeed, Weihua et al. have proposed that the testosterone

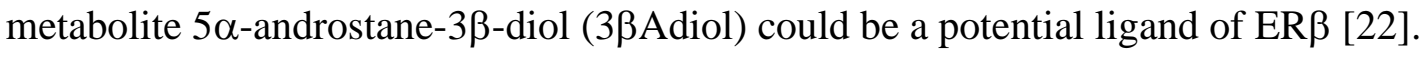
Therefore, it is possible that prostate cancer cells auto-synthesize sex-steroids, which could function as natural activators of ER $\beta$. In addition, it has also been shown that unliganded ER can transduce growth factor signals [23]. ER $\beta$ is able to recruit the coactivator, SRC-1 through phosphorylation of Ser-106 and Ser-124 by MAPK in a ligand independent manner [24]. Perhaps the ligand independent ER $\beta$ action in apoptosis involves SRC-1 interaction, or some yet unidentified pathway that is unique to $\mathrm{ER} \beta \mathrm{AF}-1$ activity.

Of particular interest is our finding that at least part of the growth inhibition triggered by $\operatorname{ER} \beta$ is due to apoptosis, demonstrating the involvement of ER $\beta$ in such events. Apoptosis of the ER $\beta$ expressing cells was shown by the increased peri-nuclear expression of cleaved 
Cheng et al.

caspase 3. The apoptosis induced by ER $\beta$ appears to involve the mitochondrial pathways, as demonstrated by the increase in Bax protein expression and the cleavage of PARP. To our knowledge, this is one of the first demonstration that $\operatorname{ER} \beta$ is able to trigger apoptosis. Indeed, a recent study has shown that ER $\beta$ could increase apoptosis in colon cancer cells [25]. A detailed analysis of this phenomenon will need to be undertaken in the future.

The fact that exogenous expression of ER $\beta$ in prostate cancer cells leads to an inhibition of proliferation and invasion and to an increase of apoptosis is in in good agreement with clinical studies showing that ER $\beta$ expression is lost in prostate, breast, ovary, colon tissues when they undergoing dysplastic transformation $[7,10,12]$. The reasons underlying ER $\beta$ loss remain poorly understood. Human ER $\beta$ promoter has been cloned recently [26] and could help to study this phenomenon. The promoter is active only in ER $\beta$ expressing cells and displays a high GC-content. Interestingly, another study has shown that ER $\beta$ promoter was methylated in about $80 \%$ of cancers but not in normal tissues [27], which could explain the down regulation of ER $\beta$ observed in cancer cells. The understanding of ER $\beta$ expression regulation will definitely constitute a challenging issue in the future, as it could lead to the development of new therapies.

In conclusion, our data support strongly the hypothesis that the loss of ER $\beta$ could be one of the key elements leading to an uncontrolled growth of prostate epithelial cells. In this model, ER $\beta$ would play a "gatekeeper" role by inhibiting invasion, proliferation and stimulating apoptosis, preventing the rapidly differentiating prostatic epithelial cells from undergoing oncogenic transformation. 
Cheng et al.

\section{Acknowledgements}

We thank Professor B. S. Katzenellenbogen for the gift of ER $\beta$ antibody, ER $\alpha$ and ER $\beta$

cDNAs. We are also grateful to the Vector Core of the University Hospital of Nantes

supported by the Association Française contre les Myopathies (AFM) for the production of

Adenovirus. This work was supported by grants from ARC (Association pour la Recherche

contre le Cancer, Grant No. 4302), la Ligue Nationale contre le Cancer (Comite du Gard),

INSERM, and CNRS. This work was performed as partial fulfilment of the doctoral thesis

of the primary author J. Cheng. 
Cheng et al.

\section{Bibliography}

[1] Schaid, D.J. (2004) Hum Mol Genet 13 Suppl 1, R103-21.

[2] Huggins, C. (1967) Cancer Research 27, 1925-30.

[3] Prins, G.S. and Birch, L. (1997) Endocrinology 138, 1801-9.

[4] Kuiper, G.G., Enmark, E., Pelto-Huikko, M., Nilsson, S. and Gustafsson, J.A. (1996) Proc Natl Acad Sci U S A 93, 5925-30.

[5] Adams, J.Y., Leav, I., Lau, K.M., Ho, S.M. and Pflueger, S.M. (2002) Prostate 52, 69-81.

[6] Leav, I., Lau, K.M., Adams, J.Y., McNeal, J.E., Taplin, M.E., Wang, J., Singh, H. and Ho, S.M. (2001) Am J Pathol 159, 79-92.

[7] Horvath, L.G. et al. (2001) Cancer Res 61, 5331-5.

[8] Fixemer, T., Remberger, K. and Bonkhoff, H. (2003) Prostate 54, 79-87.

[9] Latil, A., Bieche, I., Vidaud, D., Lidereau, R., Berthon, P., Cussenot, O. and Vidaud, M. (2001) Cancer Research 61, 1919-26.

[10] Pujol, P., Rey, J.M., Nirde, P., Roger, P., Gastaldi, M., Laffargue, F., Rochefort, H. and Maudelonde, T. (1998) Cancer Res 58, 5367-73.

[11] Campbell-Thompson, M., Lynch, I.J. and Bhardwaj, B. (2001) Cancer Res 61, 632-640.

[12] Roger, P., Sahla, M.E., Makela, S., Gustafsson, J.A., Baldet, P. and Rochefort, H. (2001) Cancer Research 61, 2537-41.

[13] Krege, J.H. et al. (1998) Proc Natl Acad Sci U S A 95, 15677-82.

[14] Weihua, Z. et al. (2001) Proc Natl Acad Sci U S A 98, 6330-5.

[15] Lazennec, G., Bresson, D., Lucas, A., Chauveau, C. and Vignon, F. (2001)

Endocrinology 142, 4120-30.

[16] McGregory, W.J., Bautista, D.S. and Graham, F.L. (1988) Virology 163, 614-7.

[17] Cowley, S.M. and Parker, M.G. (1999) J Steroid Biochem Mol Biol 69, 165-75.

[18] Paruthiyil, S., Parmar, H., Kerekatte, V., Cunha, G.R., Firestone, G.L. and Leitman, D.C. (2004) Cancer Res 64, 423-8.

[19] Strom, A., Hartman, J., Foster, J.S., Kietz, S., Wimalasena, J. and Gustafsson, J.-A. (2004) PNAS, 0308319100.

[20] Licznar, A., Caporali, S., Lucas, A., Weisz, A., Vignon, F. and Lazennec, G. (2003) FEBS Lett 553, 445-50.

[21] Freund, A., Chauveau, C., Brouillet, J.P., Lucas, A., Lacroix, M., Licznar, A., Vignon, F. and Lazennec, G. (2003) Oncogene 22, 256-65.

[22] Weihua, Z., Lathe, R., Warner, M. and Gustafsson, J.-A. (2002) PNAS 99, 13589-13594.

[23] Newton, C.J., Buric, R., Trapp, T., Brockmeier, S., Pagotto, U. and Stalla, G.K. (1994) J Steroid Biochem Mol Biol 48, 481-6.

[24] Tremblay, A., Tremblay, G.B., Labrie, F. and Giguere, V. (1999) Mol Cell 3, 513-9.

[25] Qiu, Y., Waters, C.E., Lewis, A.E., Langman, M.J. and Eggo, M.C. (2002) J Endocrinol 174, 369-77.

[26] Li, L.C., Yeh, C.C., Nojima, D. and Dahiya, R. (2000) Biochemical \& Biophysical Research Communications 275, 682-9.

[27] Sasaki, M., Tanaka, Y., Perinchery, G., Dharia, A., Kotcherguina, I., Fujimoto, S. and Dahiya, R. (2002) J Natl Cancer Inst 94, 384-90. 
Cheng et al.

\section{Legends to figures}

\section{Fig. 1. Adenovirus mediated expression of ER $\alpha$ and $E R \beta$ in DU-145 cells.}

DU-145 cells were either infected with Ad5, Ad-ER $\alpha$, Ad-ER $\beta$ viruses and transfected with $\mathrm{ERE}_{2}-\mathrm{TK}-\mathrm{LUC}$ and CMV-GAL reporter constructs. Cells were grown for $48 \mathrm{~h}$ in the presence of control vehicle ethanol (C) or $10^{-8} \mathrm{M}$ E2. Results represent the mean \pm SEM of 3 independent experiments.

\section{Fig. 2. Ad-ER $\alpha$ and Ad-ER $\beta$ inhibit cellular invasion and growth}

(A) DU-145 cells were infected with Ad5, Ad-ER $\alpha$, Ad-ER $\beta$ adenoviruses at MOI 50 and were plated on a transwell chamber coated with matrigel. Cells were treated with either ethanol (C) or $10 \mathrm{nM} \mathrm{E2}$ and allowed to invade the matrigel for 24 hours. Results represent the mean \pm SEM of 3 independent experiments.

(B) DU-145 cells were plated in a 96-well plate and infected with Ad5, Ad-ER $\alpha$, or AdER $\beta$ adenoviruses overnight at MOI 50. Fresh media containing either ethanol or $10 \mathrm{nM} \mathrm{E2}$ was added to the cells and proliferation was determined 6 days post infection. Results are expressed as $\%$ of control non infected cells and represent the mean \pm SEM of 3 independent experiments

\section{Fig. 3. ER $\beta$ induces apoptosis in DU-145 cells}

Estrogen depleted cells were infected with Ad5 or Ad-ER $\beta$ adenoviruses overnight at MOI 50. Cells were then grown for 24 or 48 hours and whole cell lysates were collected. (A) Immunoblotting using anti-Bax monoclonal antibody was performed. (B) Immunoblotting 
Cheng et al.

using anti-PARP monoclonal antibody. This antibody recognizes both intact and the $85 \mathrm{kDa}$ cleaved fragment of PARP. (C) Paraformaldehyde fixed cells were incubated with primary antibodies against cleaved caspase 3, and examined by immunofluorescence. Nuclei were stained using DAPI containing mounting medium. 